\title{
Effect of the COVID-19 pandemic on foot surgeries
}

\author{
Patryk Kuliński1,A-F, Łukasz Tomczyk ${ }^{2, B-D}$, Piotr Morasiewicz ${ }^{3, A, C-F}$ \\ ${ }^{1}$ Department of Trauma and Orthopaedic Surgery, T. Marciniak Lower Silesia Specialist Hospital - Emergency Medicine Center, Wrocław, Poland \\ 2 Department of Food Safety and Quality Management, Poznan University of Life Sciences, Poland \\ ${ }^{3}$ Department of Orthopaedic and Trauma Surgery, University Hospital in Opole, Institute of Medical Sciences, University of Opole, Poland \\ A - research concept and design; $B$ - collection and/or assembly of data; $C$ - data analysis and interpretation; \\ $D$ - writing the article; $E$ - critical revision of the article; $F$ - final approval of the article
}

Advances in Clinical and Experimental Medicine, ISSN 1899-5276 (print), ISSN 2451-2680 (online)

Adv Clin Exp Med. 2021;30(12):1249-1253

Address for correspondence

Piotr Morasiewicz

E-mail:morasp@poczta.onet.pl

Funding sources

None declared

Conflict of interest

None declared

Received on April 8, 2021

Reviewed on May 28, 2021

Accepted on July 28,2021

Published online on October 5, 2021

\begin{abstract}
Background. Musculoskeletal dysfunction due to deformities and injuries of the foot is a common orthopedic problem.

Objectives. To analyze the effect of the COVID-19 pandemic on both elective and emergency foot surgeries.

Materials and methods. This study analyzed the effect of the COVID-19 pandemic on elective and emergency foot surgeries. The comparison included data collected in 2019 (March 15-0ctober 15, when the epidemic did not influence the Polish healthcare system or patient demographics) and in a corresponding period in 2020. This study was conducted in the trauma and orthopedic surgery wards and the emergency departments of 2 regional Polish hospitals.

Results. The analysis of the data from the orthopedic wards showed a reduction in the total number of admissions in 2020 by 55\%. The number of elective and emergency interventions was differently related to the pandemic, with elective interventions declining by $72 \%$ and emergency interventions increasing by $27 \%$ in 2020 compared to 2019. The total number of elective foot surgeries in children decreased by $59 \%$ in 2020. The mean duration of hospital stay was approx. 2.5 days shorter in adults and 1.7 days shorter in children during the $2^{\text {nd }}$ evaluation period. The emergency department data showed a decline of $32 \%$ in the number of patients presenting with injuries during the pandemic. Nonetheless, the pandemic did not affect the mean age of patients and the female-to-male ratio.
\end{abstract}

Conclusions. The global COVID-19 pandemic affected the epidemiology of foot injuries as well as the prevalence of foot surgeries in children and adults.

Key words: COVID-19, pandemic, epidemiology, foot surgery, lockdown

Cite as

Kuliński P, Tomczyk Ł, Morasiewicz P. Effect of the COVID-19 pandemic on foot surgeries. Adv Clin Exp Med. 2021;30(12):1249-1253. doi:10.17219/acem/140610

DOI

10.17219/acem/140610

Copyright

Copyright by Author(s)

This is an article distributed under the terms of the

Creative Commons Attribution 3.0 Unported (CC BY 3.0)

(https://creativecommons.org/licenses/by/3.0/) 


\section{Background}

Musculoskeletal dysfunction due to deformities and injuries of the foot is a common orthopedic problem. ${ }^{1,2}$ According to the Illinois Podiatric Medical Association, approx. $6 \%$ of the USA population are affected by foot injuries, forefoot deformities or flat feet (pes planus). The global spread of severe acute respiratory syndrome coronavirus type 2 (SARS-CoV-2) infections has had an impact on many aspects of everyday life, including changes in people's habits, lifestyles and fears regarding their health and the health of their loved ones. ${ }^{2-19}$

The COVID-19 pandemic unquestionably affected the functioning of national healthcare systems. ${ }^{2-19}$ This included changes in the character of hospitals, including conversions of surgical wards into infectious wards, limiting the number of elective admissions and reducing the number of medical staff. The latter was due to temporary quarantines placed on those who had a contact with patients suspected of having COVID-19 infections and the furloughing of elderly or chronic disease-burdened staff. $^{3-5,10}$

The available literature has a limited number of reports on the effects the COVID-19 pandemic has had on foot surgeries in adults and children. ${ }^{2,4,5}$ The available reports assess the number of surgeries for foot injuries during the pandemic to a limited extent ${ }^{2}$ or estimate elective foot surgery restrictions based on surveys conducted among orthopedic surgeons. ${ }^{4,5}$

\section{Objectives}

The purpose of this study was to analyze the effect of the COVID-19 pandemic on foot surgery in both elective and emergency settings.

\section{Materials and methods}

\section{Study design and patients}

The study was conducted in the trauma and orthopedic surgery departments and the emergency departments of 2 Polish regional hospitals. Adult and pediatric patients were included in this study. The compared periods were March 15-October 15, 2019, when the (at that time nonexistent) COVID-19 epidemic did not influence the Polish healthcare system or patient demographics, and the corresponding period in 2020 (March 15-October 15, 2020). Informed consent was obtained for experimentation with human subjects. The study was approved by the local ethics committee (approval No. 4/PNDR/2021).

\section{Evaluation of epidemiological parameters}

This study analyzed the number of elective foot surgeries most commonly performed in the surgical wards, i.e., correction of forefoot deformities, including bunions (hallux valgus) and hammertoes. A large group of patients presented with multiple forefoot deformities, which were corrected simultaneously during a single procedure. Other elective procedures included arthrodesis, planovalgus foot surgery and removal of implants. The total number of elective foot surgeries in children was assessed. The procedures performed on children were divided into those most frequently performed in our departments (correction of the planovalgus foot, correction of clubfoot).

Injury interventions were divided into 2 groups. The $1^{\text {st }}$ group comprised interventions for foot fractures, defined as fractures involving any bone in the foot from the talus to the phalanges. The $2^{\text {nd }}$ group comprised interventions for injuries such as wounds, dislocations and sprains within the foot (excluding those of the ankle joint).

The groups were analyzed in terms of the number of surgeries, distribution of the sexes, age distribution, and mean duration of hospital stay. The data from 2019 were compared with the data collected in 2020.

\section{Statistical analyses}

Statistical analyses were performed using Statistica v. 13.1 software (StatSoft Inc., Tulsa, USA). The ShapiroWilk test was used to assess distribution normality. The variables did not follow a normal distribution; therefore, Pearson's $X^{2}$ test and Mann-Whitney test was used. The level of significance was set at $\alpha=0.05$.

\section{Results}

All results have been compiled in Table 1 and Table 2 . The analysis of the orthopedic ward data showed a reduction in the total number of adult admissions by $55 \%$ in 2020.

The number of elective and emergency interventions was differently affected by the pandemic, with elective interventions declining by $72 \%$ and emergency interventions increasing by $27 \%$ in 2020 compared to 2019 . These changes were statistically significant $(\mathrm{p}=0.01770$; $\mathrm{p}=0.01922$ ). In adults, arthrodesis and planovalgus foot surgeries decreased by $50 \%$ in 2020 , implant removal surgeries decreased by $63 \%$ and hallux valgus and hammertoe surgeries decreased by $82 \%$.

The total number of elective foot surgeries performed in children decreased by $59 \%$ in 2020 compared to 2019 . This difference was statistically significant $(p=0.0487)$. In children, the number of planovalgus foot surgeries decreased by $61 \%$ and clubfoot surgeries decreased by $56 \%$ in 2020 . 
Table 1. Comparison totals, means and ratios of epidemiology of foot trauma and surgery (p-value for Mann-Whitney $U$ test)

\begin{tabular}{|c|c|c|c|c|c|}
\hline \multirow{2}{*}{ Variables } & \multicolumn{2}{|c|}{$\mathrm{N}$} & \multirow{2}{*}{$\begin{array}{l}\text { Difference between the year } 2020 \text { and } 2019 \\
{[\%]}\end{array}$} & \multirow{2}{*}{ df } & \multirow{2}{*}{$p$-value } \\
\hline & 2019 & 2020 & & & \\
\hline \multicolumn{6}{|c|}{ Orthopedic surgery department - surgically } \\
\hline Total number of patients & 86 & 39 & -54.65 & - & - \\
\hline Total number of elective surgery & 67 & 19 & -71.64 & - & - \\
\hline Arthrodesis & 6 & 3 & -50.00 & - & - \\
\hline Planovalgus foot surgery & 4 & 2 & -50.00 & - & - \\
\hline Removal of implants & 19 & 7 & -63.15 & - & - \\
\hline Total number of trauma surgery & 11 & 14 & 27.27 & - & - \\
\hline Total number of patients treated conservatively & 8 & 6 & -25.00 & - & - \\
\hline Mean duration of hospital stay [days] & 6.77 & 4.28 & 36.77 & 124 & 0.02737 \\
\hline Female-to-male ratio & 2.74 & 2.00 & -26.98 & - & - \\
\hline Mean age of all patients & 56.06 & 56.05 & -0.01 & 123 & 0.9981 \\
\hline Total number of elective foot surgery in children & 27 & 11 & -59.25 & - & - \\
\hline Mean duration of hospital stay in children [days] & 5.44 & 3.72 & -31.61 & 126 & 0.0046 \\
\hline \multicolumn{6}{|c|}{ Emergency ward - conservatively } \\
\hline Total number of patients & 145 & 99 & -31.72 & - & - \\
\hline Total number of patients treated conservatively & 130 & 85 & -34.61 & - & - \\
\hline Total number of patients transferred to the orthopedic ward & 15 & 14 & -6.66 & - & - \\
\hline Female-to-male ratio & 0.59 & 0.57 & -3.7 & - & - \\
\hline Mean age of all patients & 41.26 & 45.05 & 9.13 & 242 & 0.0722 \\
\hline
\end{tabular}

Table 2. Change in composition of epidemiology of foot trauma and surgery ( $p$-value for Pearson's $x^{2}$ test)

\begin{tabular}{|c|c|c|c|c|c|}
\hline \multirow{2}{*}{ Variables } & \multicolumn{2}{|c|}{$\mathrm{N}$} & \multirow{2}{*}{$\begin{array}{l}\text { Difference between the year } 2020 \text { and } 2019 \\
\text { [\%] }\end{array}$} & \multirow{2}{*}{ df } & \multirow{2}{*}{ p-value } \\
\hline & 2019 & 2020 & & & \\
\hline \multicolumn{6}{|c|}{ Orthopedic surgery department - surgical treatment } \\
\hline $\begin{array}{l}\text { Elective surgery } \\
\text { halux valgus and hammertoe surgery } \\
\text { other surgeries }\end{array}$ & $\begin{array}{l}38 \\
29\end{array}$ & $\begin{array}{c}7 \\
12\end{array}$ & $\begin{array}{l}-81.57 \\
-58.62\end{array}$ & 1 & 0.0177 \\
\hline $\begin{array}{l}\text { Trauma surgery } \\
\text { fractures } \\
\text { other injuries }\end{array}$ & $\begin{array}{l}8 \\
3\end{array}$ & $\begin{array}{l}7 \\
7\end{array}$ & $\begin{array}{c}-12.5 \\
133.33\end{array}$ & 1 & 0.01922 \\
\hline $\begin{array}{l}\text { Gender } \\
\text { women } \\
\text { men }\end{array}$ & $\begin{array}{l}63 \\
23\end{array}$ & $\begin{array}{l}26 \\
13\end{array}$ & $\begin{array}{l}-58.73 \\
-43.47\end{array}$ & 1 & 0.451 \\
\hline \multicolumn{6}{|c|}{ Surgery in children } \\
\hline $\begin{array}{l}\text { Trauma surgery } \\
\text { planovalgus foot surgery in children } \\
\text { clubfoot surgery in children }\end{array}$ & $\begin{array}{c}18 \\
9\end{array}$ & $\begin{array}{l}7 \\
4\end{array}$ & $\begin{array}{l}-61.11 \\
-55.55\end{array}$ & 1 & 0.0487 \\
\hline \multicolumn{6}{|c|}{ Emergency ward - conservative treatment } \\
\hline $\begin{array}{l}\text { Type of injuries } \\
\text { fractures } \\
\text { injuries }\end{array}$ & $\begin{array}{l}95 \\
50\end{array}$ & $\begin{array}{l}56 \\
43\end{array}$ & $\begin{array}{l}-41.05 \\
-14.00\end{array}$ & 1 & 0.1574 \\
\hline $\begin{array}{l}\text { Gender } \\
\text { women } \\
\text { men }\end{array}$ & $\begin{array}{l}54 \\
91\end{array}$ & $\begin{array}{l}36 \\
63\end{array}$ & $\begin{array}{l}-33.33 \\
-30.76\end{array}$ & 1 & 0.889 \\
\hline
\end{tabular}

The mean duration of hospital stay for adults was approx. 2.5 days shorter in the $2^{\text {nd }}$ evaluated period, which was statistically significant (Fig. $1, \mathrm{p}=0.02737$ ). The mean duration of hospital stay for children decreased in 2020 by 1.7 days compared to 2019 . This difference was statistically significant $(\mathrm{p}=0.0046)$.
There was not a significant decrease in the proportion of females and males admitted to the hospital (with a female-to-male ratio of 2.74 in 2019 compared to 2.00 in $2020, p=0.541)$. In addition, the mean age of patients undergoing surgery remained unchanged $(\mathrm{p}=0.9981)$. 


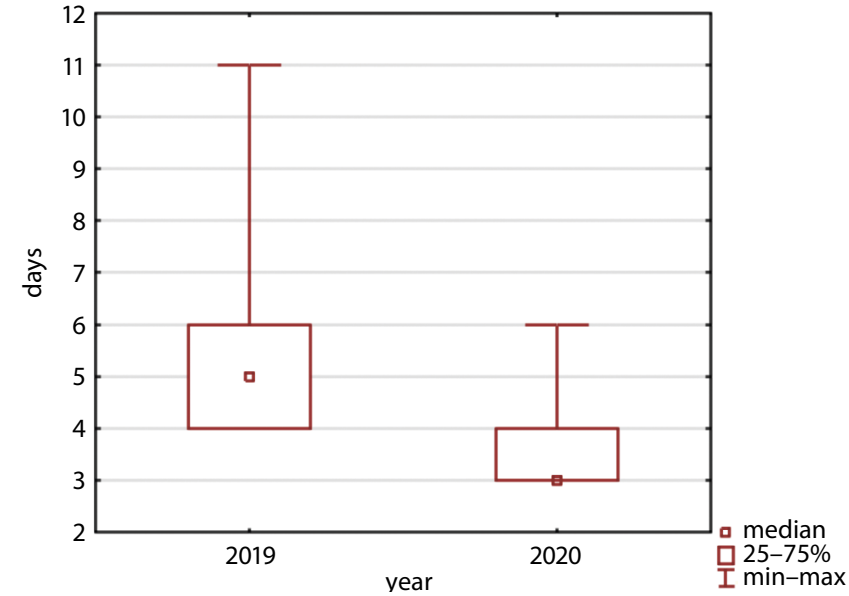

Fig. 1. Mean duration of hospital stay in days

The greatest rise in emergency procedures (133\%) was observed in interventions performed due to other foot injuries (mostly soft-tissue injuries) $(\mathrm{p}=0.01922)$. The emergency department data showed $32 \%$ fewer patients presenting with injuries during the evaluated pandemic period. These changes were statistically significant $(\mathrm{p}=0.0153)$. Moreover, the number of patients with fractures showed a greater decline (41\%) in 2020 compared with pre-pandemic figures than the number of patients with soft-tissue injuries (14\% decline), although these differences did not reach statistical significance $(\mathrm{p}=0.1574)$.

The mean patient age in the emergency ward increased from 41 years in 2019 to 45 years in 2020, but the difference was not statistically significant $(\mathrm{p}=0.0722)$. The proportion of patients seen in the emergency departments who required surgical treatment or more diagnostic tests on the orthopedic ward did not change between the evaluated periods (with only a single case fewer in the $2^{\text {nd }}$ period).

\section{Discussion}

\section{Key results and generalizability}

The COVID-19 pandemic considerably altered the organization of healthcare services across the world. ${ }^{2-19}$ Elective admissions were halted or limited, medical personnel numbers decreased and patients' fears associated with hospitalization increased. ${ }^{3-5,10}$ However, the impact of the COVID-19 pandemic on elective and emergency treatment of foot injuries has not been fully evaluated.

Our study confirms the impact of the pandemic in the form of lower numbers of elective procedures in children and adults, and shorter hospital stays to minimize the amount of contact between patients and medical staff, who are the potential vectors in coronavirus transmission. Similarly, other authors have reported decreases in the number of elective procedures during the pandemic by $23-100 \% .^{3-5,10}$ An estimated $26.6-75.2 \%$ of centers cancelled or rescheduled (postponed) foot surgeries during the COVID-19 pandemic. ${ }^{4,5}$ We observed a decrease in all types of elective surgeries performed in both, adults and children. The reduction in the number of elective admissions of children during the COVID-19 pandemic, observed in our study, may have negative effects in the form of increasing the severity of deformities in patients awaiting surgery. The postponing of any musculoskeletal surgery in a growing child is particularly dangerous, and can have irreversible consequences and a significant impact on their health.

No statistically significant reduction was seen in the ratio of female-to-male patients admitted to orthopedic surgery departments in 2020, largely due to the fact that females are generally more prone to develop forefoot deformities..$^{20,21}$

During the pandemic, the introduction of travel restrictions and remote work led to fewer patients presenting with pain, which undoubtedly resulted in a reduction of patients admitted for elective forefoot procedures. In many cases, patients decided to postpone their treatment due to less severe pain, and - particularly among the elderly - out of fear of the coronavirus.

In contrast to the pronounced change in sex distribution among orthopedic ward patients, the change in sex distribution among emergency room patients was negligible. Males presented nearly 2 times more frequently than females in both evaluated periods (the female-to-male ratio was 0.59 in 2019 and 0.57 in 2020), which indicates a higher incidence of foot injuries in males.

The increased number of foot injury patients transferred to the orthopedic ward from the emergency room to undergo surgical treatment was due to several factors. These include the increasingly stringent restrictions imposed by the Polish government during the period of national lockdown, which directly affected the etiology of injuries, with lower numbers of high-energy injuries and only slightly lower numbers of soft-tissue injuries. These changes were a result of travel restrictions and the consequent decline in the number of traffic accidents. ${ }^{13,15,18}$ Conversely, the amount of work around the house increased due to no restrictions being imposed on hardware and DIY stores. This, combined with increased alcohol consumption, resulted in a higher incidence of injuries at home. ${ }^{13,15,18}$ Moreover, heavy industry did not experience any direct lockdown measures, which was associated with undiminished injuries in this field.

\section{Limitations}

The limitation in the assessment of the impact of the COVID-19 pandemic on foot surgery is that it was only conducted at 2 centers and on a limited group of patients. This allowed the authors to quickly assess and present the important research results. However, in the future, we plan to conduct a multicenter study on a larger group of patients. 
In light of the uncertain future and lack of reliable estimates as to the duration of this pandemic, orthopedic wards and surgery scheduling must develop protocols to increase their availability and ensure the safety of patients and staff.

\section{Conclusions}

Our analysis of the collected data showed the effects of the global COVID-19 pandemic on the types of patients, availability of elective foot surgeries in children and adults, and epidemiology of foot injuries. This study highlights the need to make elective surgeries more available, while simultaneously improving the safety for both hospital staff and patients by minimizing the risk of possible SARS CoV-2 transmission. The COVID-19 pandemic saw a reduction in the number of all types of elective foot surgeries in children and adults, an increase in the number of trauma-related foot surgeries, and shortening of hospital stays. Nonetheless, the pandemic had no effect on mean patient age and female-to-male ratio.

\section{ORCID iDs}

Patryk Kuliński (1) https://orcid.org/0000-0002-1048-7460 Łukasz Tomczyk (1) https://orcid.org/0000-0002-4644-0111

Piotr Morasiewicz (1) https://orcid.org/0000-0002-7587-666X

\section{References}

1. Cichero MJ. Elective foot and ankle surgery: Activity and perioperative complications in Queensland public hospitals, Australia. Foot (Edinb). 2009;19(3):139-144. doi:10.1016/j.foot.2009.02.003

2. Vosoughi AR, Borazjani R. COVID-19 effect on foot \& ankle surgery in Shiraz, south Iran. J Foot Ankle Surg. 2020;59(5):887. doi:10.1053/j. jfas.2020.06.013

3. Thaler M, Khosravi I, Hirschmann MT, et al. Disruption of joint arthroplasty services in Europe during the COVID-19 pandemic: An online survey within the European Hip Society (EHS) and the European Knee Associates (EKA). Knee Surg Sports Traumatol Arthrosc. 2020;28(6): 1712-1719. doi:10.1007/s00167-020-06033-1

4. Liebensteiner MC, Khosravi I, Hirschmann MT, Heuberer PR, Thaler M Board of the AGA - Society of Arthroscopy and Joint-Surgery. Massive cutback in orthopaedic healthcare services due to the COVID-19 pandemic. Knee Surg Sports Traumatol Arthrosc. 2020;28(6):1705-1711. doi:10.1007/s00167-020-06032-2

5. Liebensteiner MC, Khosravi I, Hirschmann MT, Saffarini M, Thaler $M_{4}$ The Board of the AGA - Society of Arthroscopy and Joint-Surgery. It is not 'business as usual' for orthopaedic surgeons in May 2020: The Austrian-German-Swiss experience. J Exp Orthop. 2020;7:61. doi:10.1186/s40634-020-00272-4

6. Kort NP, Gomez Barrena E, Bédard M, et al. Resuming elective hip and knee arthroplasty after the first phase of the SARS-CoV-2 pandemic: The European Hip Society and European Knee Associates recommendations. Knee Surg Sports Traumatol Arthrosc. 2020;28(9):2730-2746. doi:10.1007/s00167-020-06233-9
7. Kort NP, Gomez Barrena E, Bédard M. Recommendations for resuming elective hip and knee arthroplasty in the setting of the SARS-CoV-2 pandemic: The European Hip Society and European Knee Associates Survey of Members. Knee Surg Sports Traumatol Arthrosc. 2020;28(9): 2723-2729. doi:10.1007/s00167-020-06212-0

8. Kort NP, Zagra L, Gomez Barrena E. Resuming hip and knee arthroplasty after COVID-19: Ethical implications for wellbeing, safety and the economy. Hip Int. 2020;30(5):492-499. doi:10.1177/1120700020941232

9. Athey AG, Cao L, Okazaki K. Survey of AAHKS International Members on the impact of COVID-19 on hip and knee arthroplasty practices. J Arthroplasty. 2020;35(7S):S89-S94. doi:10.1016/j.arth.2020.04.053

10. D'Apolito R, Faraldi M, Ottaiano I, Zagra L. Disruption of arthroplasty practice in an orthopedic center in northern Italy during the coronavirus disease 2019 pandemic. J Arthroplasty. 2020;35(7S):S6-S9. doi:10.1016/j.arth.2020.04.057

11. Verde F, D'Ambrosi R, Biazzo A, Masia F, Perazzo P. Guidelines for resuming elective hip and knee surgical activity following the COVID-19 pandemic: An Italian perspective [Epub ahead of print]. HSS J. 2020; 13:1-6. doi:10.1007/s11420-020-09809-w

12. Donell ST, Thaler M, Budhiparama NC, et al. Preparation for the next COVID-19 wave: The European Hip Society and European Knee Associates recommendations. Knee Surg Sports Traumatol Arthrosc. 2020; 28(9):2747-2755. doi:10.1007/s00167-020-06213-z

13. Upadhyaya GK, lyengar K, Jain VK, Vaishya R. Challenges and strategies in management of osteoporosis and fragility fracture care during COVID-19 pandemic. J Orthop. 2020;21:287-290. doi:10.1016/j. jor.2020.06.001

14. Hashmi P, Fahad S, Khan HN, Zahid M, Sadruddin A, Noordina S. Covid-19 pandemic: Economic burden on patients with musculoskeletal injuries in a tertiary care hospital of LMIC. Retrospective cross sectional study. Ann Med Surg (Lond). 2020;60:5-8. doi:10.1016/j. amsu.2020.09.049

15. Yu P, Wu C, Zhuang C, et al. The patterns and management of fracture patients under COVID-19 outbreak in China. Ann Transl Med. 2020;8(15):932. doi:10.21037/atm-20-4174

16. Maryada VR, Mulpur P, Guravareddy AV, Pedamallu SK, Bhasker BV. Impact of COVID-19 pandemic on orthopaedic trauma volumes: A multi-centre perspective from the state of Telangana. Indian JOrthop. 2020;54(Suppl 2):1-6. doi:10.1007/s43465-020-00226-z

17. Mitkovic MM, Bumbasirevic M, Milenkovic S, Gajdobranski D, Bumbasirevic V, Mitkovic MB. Influence of coronavirus disease 2019 pandemic state of emergency in orthopaedic fracture surgical treatment. Int Orthop. 2021;45(4):815-820. doi:10.1007/s00264-020-04750-3

18. Murphy T, Akehurst H, Mutimer J. Impact of the 2020 COVID-19 pandemic on the workload of the orthopaedic service in a busy UK district general hospital. Injury. 2020;51(10):2142-2147. doi:10.1016/j.injury. 2020.07.001

19. Lv H, Zhang Q, Yin Y, et al. Epidemiologic characteristics of traumatic fractures during the outbreak of coronavirus disease 2019 (COVID-19) in China: A retrospective \& comparative multi-center study. Injury. 2020;51(8):1698-1704. doi:10.1016/j.injury.2020.06.022

20. Roddy E, Zhang W, Doherty M. Prevalence and associations of hallux valgus in a primary care population. Arthritis Rheum. 2008;59:857-862. doi:10.1002/art.23709

21. Nix S, Smith M, Vicenzino B. Prevalence of hallux valgus in the general population: A systematic review and meta-analysis. J Foot Ankle Res. 2010;3:21. doi:10.1186/1757-1146-3-21 